Article

\title{
Development of Vocational Maturity in University Students with Disabilities to Access, Obtain an Internship and Complete University Studies
}

\author{
Rosa Espada-Chavarria ${ }^{1, *(\mathbb{D})}$, Ricardo Moreno-Rodriguez ${ }^{1}(\mathbb{D})$ and Cristina Jenaro $^{2}(\mathbb{D}$ \\ 1 Department of Educational Sciences, Rey Juan Carlos University, 28032 Madrid, Spain; \\ ricardo.moreno@urjc.es \\ 2 INICO, Faculty of Psychology, University of Salamanca, 37007 Salamanca, Spain; crisje@usal.es \\ * Correspondence: rosa.espada@urjc.es
}

Received: 9 November 2020; Accepted: 8 December 2020; Published: 17 December 2020

check for updates

\begin{abstract}
In recent years, there has been a considerable increase in the number of university students with disabilities in Spain, as in other countries. Access to and completion of studies in higher education has been identified as a factor that improves the educational and labor inclusion of these people. However, this group of students faces difficulties in completing their studies, as they encounter problems in carrying out their internships, which is an obligatory element of many degrees. Our quantitative research study presents the results of the Generating Professional Skills (GPS) program for the development of vocational maturity based on training itineraries, carried out by the University Unit of Attention to People with Disability. The main results show an increase in vocational maturity and position tutoring as a fundamental part of the educational inclusion process, as well as a key role of the support services for those with disabilities to experience a more inclusive and quality education, thus aligning with objective 4 of the 2030 Sustainable Development Goals. SDG. The information collected allows us to conclude that these programs increase the vocational maturity and the knowledge and competencies of students with disabilities and, therefore, are key elements for the success in accessing and obtaining internships and for the successful completion of their studies.
\end{abstract}

Keywords: inclusive education; vocational maturity; higher education; internship; disability support offices; soft skills

\section{Introduction}

The inclusion of internships as a curricular subject for university degrees represents a major change experienced by universities since the establishment of curricula adapted to the European Higher Education Area, together with the modification of teacher training methods, students' ways of working, and incentives for international mobility. Competency-based learning is undoubtedly one of the relevant elements of the training model proposed by the European Higher Education Area EHEA [1-4], in addition to the students' autonomous work, the reinforcement of both academic tutoring, and more appropriate evaluation systems in which the student plays the leading role $[5,6]$.

In Spain, as in other countries [7,8], the number of students with disabilities has recently increased, although this group of students still constitutes a relatively low percentage of the total number of students. In fact, during the academic year 2005-2006, the figure for this group was 7247 individuals [9], rising to 22,190 in the academic year 2018-2019, according to the guidelines for the support of persons with disabilities in universities introduced by the Universia Foundation in the "IV Study on University and Disability" [10]. The data regarding the total number of individuals who access and complete 
their university studies stands at $19.9 \%$; however, only $7 \%$ of students with disabilities have academic qualifications. Thus, the representation of students with disabilities at university is reduced to $1.5 \%$ of the total number of university students. Nevertheless, data from the National Statistics Institute [11] (Table 1), indicate that, although the activity rate is substantially higher among people without disabilities, this figure increases in both cases (people with and without disabilities) when the level of education is higher. This demonstrates that university students with disabilities have a greater ability to adapt to the labor market [12]; therefore, university represents the most adequate field of knowledge and training in order to achieve the full incorporation of people with disabilities into society $[9,13,14]$.

Table 1. Activity rate by study level (\%).

\begin{tabular}{llll}
\hline & Total & Without Disabilities & With Disabilities \\
\hline Total & 75.10 & 77.00 & 36.60 \\
Illiterate persons & 31.50 & 47.80 & 4.40 \\
Primary education & 57.10 & 60.80 & 23.10 \\
Secondary education, training, and & 73.80 & 75.00 & 44.40 \\
employment programs & 88.20 & 88.90 & 57.30 \\
Higher education, including doctoral degree & &
\end{tabular}

This increase in people with disabilities undertaking higher studies implies a wider range of graduates seeking an internship and/or employment in line with the students' knowledge, abilities, competences, and skills. However, taking into consideration employment and training data on people with and without disabilities, it would seem natural that these percentages mask a number of additional difficulties that act as barriers to the recruitment of people with disabilities [15-18], including for internships [19]. Mandatory training practices in practically all university degrees adapted to the European Higher Education Area oblige students to face one of the most challenging tasks, that is, searching for a job $[19,20]$. Though we are referring to the search for training internships in this case, the process is similar to search for employment, since the demand for these positions is such that companies also carry out selection processes among those who wish to access them [21,22]. In these recruitment processes, there may be situations where employers, who are not aware of the factors surrounding disabilities, may not consider selecting someone with a disability if there are candidates who meet the profile of the internship or job offered, and who have not disclosed any disability [23]. This fact is another barrier that students with disabilities have to face during their task of searching and obtaining an internship offer that suits their interests, motivations, abilities, or skills, and that fits their functions to the demands of the degree they are studying. For this reason, it is necessary to design and implement training programs that develop their competences, abilities, and social skills, which increase the probability of success, both when facing the selection processes, and the maintenance of the practices after their incorporation.

Both the ability to seek a job or internship and to obtain one are factors that can be measured as indicators of the level of vocational maturity relevant to employment. Such factors focus on a very specific moment in life, namely, young people on the threshold of the labor market [19,24-26]. This academic stage, in which students complete their studies with practical experience in a real working environment, requires them to develop a range of skills and competences that enable students to carry out this step and attain the highest level of success. On the other hand, it is important to mention that, although the classroom is essential with regard to the acquisition of generic competences, teachers rarely include them in their academic learning outcomes, as a result of deficiencies in their teacher training [27]. Furthermore, it must be remembered that an internship is a curricular subject that students must pass in order to graduate.

Considering this situation, it seems appropriate to offer support to students with disabilities who experience difficulties in academic decisions, lack of knowledge of their skills, difficulties in the planning of strategies for decision-making, and searching for solutions to their vocational situation [28]. On the other hand, the research of [29] on how practices should be designed in the European Higher 
Education Area, guides, through its results, the importance of designing a practical subject from a training plan based on competences, since practices in real learning environments allow the evaluation of not only knowledge and skills but also of competences. This model, in turn, allows the students themselves to be aware of their level of competence in a real situation, that is, to evaluate themselves and, consequently, to improve their self-learning. However, the task of accompanying the teacher in this educational process is still necessary. That is why [30], in their research on institutional tutorial action programs in which the opinions of their university tutors were reflected, after the implementation of the programs, they determined that academic tutoring allowed the generation of collaborative spaces for reflection on practice and, consequently, in which students jointly evaluated their achievements and difficulties.

From this perspective, tutoring becomes the perfect ally to overcome obstacles and difficulties, taking into account that we live in an increasingly complex real environment, just as they will advance [31] in their contribution to the creation and development of the European Higher Education Area, whose implementation has required the search for consensus to reach reference points based on competences, skills, and abilities. However, the study carried out by [32] on university tutoring in the European context shows that it is rarely used despite the fact that tutorial action at university is considered a great option for advice and support in the acquisition and maturation of the competitions. This is precisely why [20] shares the usefulness of this type of training program, to promote not only the quality of education but also the employability and professional development of the students.

These services provided by the University, on its path to inclusive education, would be framed within the mechanisms to respond to diversity among learners in the classroom in order to ensure equality of opportunity, non-discrimination, and universal accessibility [33], in accordance with Organic Law 4/2007 of 12 April 2007 (amending Organic Law 6/2001 of 21 December 2001) which governs universities (in its 23rd additional provision) to establish positive action measures to ensure the full and effective participation of people with disabilities at the university level.

Based on this situation, the research reported in this paper explores the experiences of students with disabilities in the last years of their degrees at the Universidad Rey Juan Carlos, who are planning to do an internship. The research conducted was part of a larger study in which the design of the orientation and training program for general skills, based on individualized itineraries (GPS-Generating Professional Skills), was carried out. Therefore, the purpose of this study was to analyze if the realization of the GPS program increases the level of vocational maturity and knowledge of the general competences of the university students with disabilities in their last years of their degree at Rey Juan Carlos University, determining whether the program increases the probability of success in facing academic tasks and subjects, including training practices and future employment. The objectives set out above are formulated according to the following hypotheses:

Hypothesis 1 (H1): Participants will have a low level of vocational maturity.

Hypothesis 2 (H2): Participants will be unaware of the generic and specific competences related to their degree, as well as the meaning and limited development of these skills.

Hypothesis 3 (H3): The vocational maturity level of participants will increase through the implementation of a training program in transversal skills.

Regarding the description of the service where the sample is located, the Unit for People with Disabilities and Specific Educational or Labor Needs (UAD) is a service of the Rey Juan Carlos University, which has been offering this service since 2005.

The main objective of the UAD, as stated in the regulations approved by the Governing Council in April 2008, is that "those members of the University Community (students, professors, and administrative and service staff) who present any type of disabilities or special educational need 
may enjoy the same opportunities as the rest for the development of their university studies, or for the performance of their jobs, under the prism of equal opportunities".

According to the latest data, available in the 1985-2019 Statistical Yearbook of the Community of Madrid [34,35], during the 2017-2018 academic year, Universidad Rey Juan Carlos was positioned as the second university with the greatest number of students in the Community of Madrid, with 46,451 students. It is worth noting that, of the total number of students, nearly $2 \%$ are students with disabilities.

\section{Materials and Methods}

This research was based on a pre-experimental and quasi-experimental study with a one-group pretest-posttest design and a duration of one year. All participants met the following inclusion and exclusion criteria: to be in possession of a certificate proving the degree of disability; to be a student in the last years of the degree (third or fourth academic year) in a position to carry out the internship component included within the degree; and not having previously been able to access internships through the standard procedures for all students at the university, despite having informed the Disability Support Office of their intention to start their internship.

The sample population selected consisted of 41 university students with disabilities, which eventually reduced to 29 because of academic development reasons unrelated to the implementation of this research.

The questionnaire applied was an adaptation of the Vocational Maturity Interview (VMI) $[25,26,36]$, a 10-item structured interview composed of ten open questions. The VMI informs about three main factors associated with vocational maturity that deal with occupational choice: the search for information, the knowledge of professional requirements, and professional identity. Factor 1 (F1), the search for information, is composed of items 1, 2, 4 and 9, and measures activities and specific efforts to understand the world of work and occupational information of interest to the assessed students. This factor is in line with aspects of vocational maturity regarding specific efforts for the purpose of acquiring knowledge in the world of work and job seeking. It has a value of 2.12 and a total variance of $21.2 \%$. Factor 2 (F2), the knowledge of professional requirements, is composed of items 5, 7 and 8, and it refers to the self-appraisal of abilities relevant to job performance; it is not about actions taken, but rather beliefs, values, and judgments in terms of the level of self-knowledge and occupational information. It has a value of 1.29 and a total variance of $12.9 \%$. Finally, Factor 3 (F3) is composed of items 3, 6 and 10, and refers to orientation to work, that is, clarity about the profession that the subjects of this research would like to carry out. It has a value of 1.08 and a total variance of $10.8 \%$. It assigns a score from 0 to 2 that results in a total VMI score of 22 points. Validity and reliability studies of VMI have been carried out in the United States and Spain [25,36,37]. It comprises a sociodemographic data collection questionnaire and semi-structured interview to assess the students' knowledge of skills and competences.

For analysis, the arithmetic mean, standard deviation, the median, and the interquartile range were used as indices of central tendency and dispersion for quantitative variables of the sampling distribution, depending on the assumption or not, respectively, of normality determined with the Shapiro-Wilks (S-W) test. The measure of association between two categorical variables was done by Pearson's $\chi 2$ or Fisher's exact test if both were dichotomous, in which case the effect assessment was performed by risk estimation, with an accuracy of a 95\% confidence range. To determine the association between a dichotomous independent variable and a variable quantitatively dependent on parametric distribution, the Student t-test was used for independent and dependent sampling, depending on whether they matched or not, respectively, the sampling distribution. In both cases, the effect was assessed through the mean difference and accuracy by a $95 \%$ confidence range. If the dependent variables violated the assumption of normality (S-W), the Mann-Whitney U test was used for independent samples, or the Wilcoxon test for paired samples. The effect measure was evaluated 
through the difference between the medians. In all cases, a value of $p<0.05$ was used as a level of statistical significance with the SPSS Statistics v22 software.

Regarding design and procedure, individual meetings were convened for the students requesting academic support at the Disability Support Office. These students with disabilities had expressed interest in initiating an internship and previously failed in the selection processes carried out by companies. Participants were informed of the research and gave informed consent to participate in the study. We guaranteed their anonymity and the confidentiality of all data collected. Participants were also informed that they could withdraw from the study at any time, and their data would then be deleted and would not be included in the analysis.

In the first interview and after the initial contact (obtaining sociodemographic data and information about their personal stories and disabilities), the Vocational Maturity Interview (VMI) was answered orally, as indicated in the instructions.

Participants were summoned to the second tutoring, after asking them whether they had consulted the study guides for their degree besides the transversal skills associated with their university studies. Then, they were asked to define each of the 15 competences previously selected from the different categories of the Tuning project. The answers were noted literally by the experimenter, who categorized them according to the definitions included in the training program. Before starting, the participants were informed that the time available for answering the questions was $15 \mathrm{~min}$, making it necessary for them to specify and define their answers. After completing this initial assessment on the knowledge of competences, a work plan was designed, mainly based on training transversal skills through academic tutoring, according to their needs. During this tutoring, an individualized training program was initiated, firstly, assessing the importance of both the knowledge and development of these skills (extremely useful in academic and training processes).

Training, information, and practical activities were provided to develop seven competences that were selected from the Tuning project, mainly in the instrumental area because they are the first to be acquired before the systemic and personal ones. However, one of each of the remaining areas was incorporated, that is, one from the personal area and one from the systemic area, namely, Instrumental Competences: information management skills, concern for quality, ability to work under pressure, problem-solving, and decision making; Interpersonal competences: Teamwork (co-operation); Systemic competences: motivation. Once the training content was completed, the assessment was repeated.

The total number of participants was 41 , as mentioned above, of whom 26 were men $(63.4 \%)$ and 15 were women $(36.6 \%)$. The median age was $26(\mathrm{SD}=7.06 ; \max =52, \min =19)$, with a range of 19 to 52 years of age. With respect to marital status, most of the participants were single $(87.8 \%$, compared with $12.2 \%$ of students who were married), living in the family home $(87.8 \%$, compared with $12.2 \%$ of students who lived independently). The following degrees are the ones in which most participants were registered: Business Administration and Management, Law, Tourism, Software Engineering, Accounting and Finance, Audiovisual Communication, and, finally, the dual degree in Chemical Engineering and Energy Engineering. The degrees with fewer participants were Advertising and Public Relations, Biology, International Relations, and the dual degrees in Engineering and Industrial Organization, and Computer Engineering and Business Administration and Management. Regarding the type of disability, $41.5 \%$ of the students had a physical disability, $6 \%$ had a visual disability, $6 \%$ had a psychological disability, and $4 \%$ had a sensory disability. Furthermore, $4 \%$ of the subjects had physical and psychological disabilities simultaneously, while another $4 \%$ had physical and sensory disabilities.

The most prevalent degree of disability among the students was $33 \%$, at an average of $54 \%$ $(\mathrm{SD}=20.36)$. Half of the sample receive benefits, whereas the rest of them do not. It was detected that $26.8 \%$ of the participants were exposed to family overprotection. Considering the level of proficiency in a foreign language (according to the Common European Framework of Reference for Languages) $4.9 \%$ had a level equivalent to $\mathrm{C} 2,17.1 \%$ to $\mathrm{C} 1$, and $24.4 \%$ to $\mathrm{B} 2 ; 53.7 \%$ had a $\mathrm{B} 1$ level, being the most basic level (equivalent to the level required to access their respective degrees). Only $5 \%$ had computer skills equivalent to a programming level, and 37.5\% had knowledge of office computing 
and advanced software. The remaining $57.5 \%$ only had knowledge in office computing. Additionally, $62.5 \%$ had a driver's license and only $9.8 \%$ were working, in contrast to the $90.2 \%$ of students who were only studying.

\section{Results}

\subsection{Vocational Maturity Level of Students with Disabilities Enrolled in the Disability Support Office of the Rey} Juan Carlos University

With regard to the total score of VMI, it should be noted that, as far as the pre-test moments are concerned, the analyzed sample rose to 41 subjects, as detailed above. As illustrated in Table 2, the results obtained show, in terms of the total score, that the range of scores was from 9 to 20 points, while the average score was $13.3(\mathrm{SD}=2.88)$, although the highest proportion of subjects had intermediate scores (65.5\% of the sample had 11 to 15 points). These results reveal a low level of vocational maturity among participants in correlation with the tool used. These data allow us to confirm the first hypothesis.

Table 2. Distribution of total score obtained through Vocational Maturity Interview (VMI) at an early stage.

\begin{tabular}{cccc}
\hline Score & $\mathbf{N}$ & $\mathbf{\%}$ & \% Accumulated \\
\hline 9 & 3 & 7.3 & 7.3 \\
10 & 3 & 7.3 & 14.6 \\
11 & 6 & 14.6 & 29.3 \\
12 & 7 & 17.1 & 46.3 \\
13 & 5 & 12.2 & 58.5 \\
14 & 5 & 12.2 & 70.7 \\
15 & 4 & 9.8 & 80.5 \\
16 & 2 & 4.9 & 85.4 \\
17 & 2 & 4.9 & 90.2 \\
18 & 1 & 2.4 & 92.7 \\
19 & 1 & 2.4 & 95.1 \\
20 & 2 & 4.9 & 100 \\
Total & 41 & 100 & \\
\hline
\end{tabular}

As can be observed in Table 3, the score decreased in line with the different factors. More specifically, the scores were higher considering the ability to search for information (F1), lower in relation to the knowledge of professional requirements (F2), and Professional Identity (F3), the factor associated with guidance towards employment, shows similar scores to the first factor. These three factors denote a progressively more complex vocational maturity, since the first factor is related to the abilities useful when choosing a job, while the other two factors are related to the ones needed to obtain it.

Table 3. Distribution of total score obtained through VMI. Previous results.

\begin{tabular}{cccccc}
\hline Title 1 & N & Minimum & Maximum & M & SD \\
\hline F1VMIPRE & 41 & 0.50 & 2.00 & 1.2317 & 0.40462 \\
F2VMIPRE & 41 & 0.25 & 2.00 & 1.0915 & 0.45674 \\
F3VMIPRE & 41 & 0.67 & 1.67 & 1.3171 & 0.25767 \\
\hline
\end{tabular}

By undertaking further analysis using the Student $t$-test, it has been demonstrated that, on the basis of the gender of the participants, there is neither significant difference in respect to the ability to search for information $(\mathrm{F}=0.042 ; p=0.838)$, nor contrast in guidance towards employment $(\mathrm{F}=0.992 ; p=0.32)$, although differentiation can be observed according to the knowledge of professional requirements $(\mathrm{F}=5.79 ; p=0.021)$. No significant differences were detected in the following aspects: previous work experience, overprotection, being currently working, computer knowledge, and/or relevant allowances. 
Depending on the degree of disability, the variable was recoded in such a way to result in two groups: one group with a degree of disability lower than $65 \%$ and the other higher. No significant differences were detected with the Student $t$-test in the ability to search for information $(F=0.124 ; p=0.726)$, or in the guidance toward employment $(\mathrm{F}=1.73 ; p=0.196)$. In contrast, a significant difference could be observed with regard to the knowledge of professional requirements $(\mathrm{F}=5.55 ; p=0.024)$.

\subsection{Knowledge of Generic Competences in University Studies}

Regarding the knowledge of generic competences, the sample was reduced to 29 subjects who responded to all questions. Analyzing the possible existence of a relationship between knowledge of generic competences and previous work experience in any field through the Student t-test, only a significant relationship was found with the 12th competence (Sense of Initiative and Entrepreneurship; $\mathrm{F}=7.56, p=0.010$ ). No relationship was found with the academic year in which the participants were enrolled. With regard to the chi-square test to assess the students' knowledge of each competence, the results are reported in Table 4.

Table 4. Chi-square test to assess students' initial knowledge of each generic competence (GCI).

\begin{tabular}{cccc}
\hline Competence & Chi-Square & df & $p$ \\
\hline GCI-1 & 8.345 & 2 & 0.015 \\
GCI-2 & 11.655 & 2 & 0.003 \\
GCI-3 & 24.069 & 2 & 0 \\
GCI-4 & 19.931 & 2 & 0 \\
GCI-5 & 13.517 & 2 & 0.001 \\
GCI-6 & 14.966 & 2 & 0.001 \\
GCI-7 & 17.034 & 2 & 0 \\
GCI-8 & 2.138 & 2 & 0.343 \\
GCI-9 & 2.138 & 2 & 0.343 \\
GCI-10 & 11.241 & 2 & 0.004 \\
GCI-11 & 13.310 & 2 & 0.001 \\
GCI-12 & 28.414 & 2 & 0 \\
GCI-13 & 14.345 & 2 & 0.001 \\
GCI-14 & 6.276 & 2 & 0.043 \\
GCI-15 & 0.276 & 2 & 0.871 \\
\hline
\end{tabular}

Note: df: Is the degree of freedom for the chi-square test. GCI: initial knowledge of each generic competence.

Almost all the skills are unknown, except for GCI-3 (Decision-making), GCI-4 (Critical thinking), GCI-7 (Problem-solving). We can see how the GCI-15 produces higher levels, but we have ruled this one out since it is frequently used as an example before testing (due to its systemic nature and the fact that it not assessable in the post-test). These data permit the verification of the second hypothesis of this research.

\subsection{Post-Treatment Improvement in Vocational Maturity of Students with Disabilities}

The following data correspond to 24 participants of the 41 subjects in the initial sample. Of the 29 students who began the training program, 5 dropped out owing to motives such as a change of residence, medical reasons associated with the disability, and, mainly, uncertainty about combining academic work at university and attendance to the internships at the companies. Thus, the total number of participants who completed this study was 24 students with disabilities.

The results illustrated in Table 5 show that item 3 increases significantly together with item 10 . Both items, 3 and 10, are included in Factor 3, which assesses professional identity, that is to say, the clarity about the profession that the students would like to carry out, as well as the association of the students' skills and abilities with professional profiles. Thus, these data confirm what was expected in Hypothesis 3. 
Table 5. Student $t$-test for samples related to the items from the Vocational Maturity Interview.

\begin{tabular}{cccccccccc}
\hline & Pre & & \multicolumn{9}{c}{ Post } & & \multicolumn{1}{c}{$t$} \\
\hline & $\mathrm{M}$ & $\mathrm{N}$ & $\mathrm{SD}$ & $\mathrm{SE}$ & $\mathrm{M}$ & $\mathrm{N}$ & $\mathrm{SD}$ & $\mathrm{SE}$ & \\
VMI1 & 1.08 & 24 & 0.65 & 0.13 & 1.08 & 24 & 0.65 & 0.13 & \\
VMI2 & 1.08 & 24 & 0.65 & 0.13 & 1.08 & 24 & 0.65 & 0.13 & -7.620 \\
VMI3 & 1.04 & 24 & 0.36 & 0.07 & 1.83 & 24 & 0.38 & 0.08 & \\
VMI4 & 0.96 & 24 & 0.91 & 0.19 & 0.96 & 24 & 0.91 & 0.19 & \\
VMI5A & 0.38 & 24 & 0.71 & 0.15 & 0.38 & 24 & 0.71 & 0.15 & -4.628 \\
VMI5B & 1.08 & 24 & 0.78 & 0.16 & 1.83 & 24 & 0.38 & 0.08 & \\
VMI6 & 1.88 & 24 & 0.34 & 0.07 & 2.00 & 24 & 0.00 & 0.00 & -5.318 \\
VMI7 & 1.25 & 24 & 0.53 & 0.11 & 1.88 & 24 & 0.34 & 0.07 & -3.191 \\
VMI8 & 1.25 & 24 & 0.53 & 0.11 & 1.63 & 24 & 0.49 & 0.10 & \\
VMI9 & 1.63 & 24 & 0.65 & 0.13 & 1.63 & 24 & 0.65 & 0.13 & -6.802 \\
VMI10 & 0.96 & 24 & 0.62 & 0.13 & 1.92 & 24 & 0.28 & 0.06 & -13 \\
\hline
\end{tabular}

Note: M: Median M; N: Sample number N; DT: standard deviation SD; ET: standard error SE.

Significant improvement can be found in the total scores on the scale, as shown in Table 6, below. The ability to make reasoned decisions in the future considering their work-related preferences is thus expected.

Table 6. Student $t$-test for samples related to the factors in the Vocational Maturity Interview.

\begin{tabular}{lccccccccc}
\hline & $\mathbf{M}$ & $\mathbf{N}$ & SD & SE & M & N & SD & SE & $t$ \\
\hline TOTAL VMI & 12.71 & 24.00 & 2.63 & 0.54 & 16.21 & 24.00 & 2.32 & 0.47 & -10.443 \\
PERCENTILE & 52.29 & 24.00 & 21.36 & 4.36 & 81.08 & 24.00 & 14.39 & 2.94 & -8.716 \\
$\quad$ F1VMI & 1.19 & 24.00 & 0.36 & 0.07 & 1.19 & 24.00 & 0.36 & 0.07 & \\
F2VMI & 0.99 & 24.00 & 0.39 & 0.08 & 1.43 & 24.00 & 0.30 & 0.06 & -6.307 \\
F3VMI & 1.29 & 24.00 & 0.25 & 0.05 & 1.92 & 24.00 & 0.18 & 0.04 & -10.804 \\
\hline
\end{tabular}

In addition, Table 7 shows the percentages that reflect the knowledge of each of the seven competences selected in the pre- and post-test, since they are the first to be developed. Substantial improvements can be observed. However, results with regard to decision-making skills should be higher, given the course and the vital moment at which participants are, although it corresponds to expectations.

Table 7. Comparison of the scores in the post-test moment. Knowledge of generic competences.

\begin{tabular}{clc}
\hline Competence & Pre & Post \\
\hline Curiosity, ability to search and information management (GCI-2) & $6.9 \%$ & $95.7 \%$ \\
Ability to work autonomously and decision-making (GCI-3) & $6.9 \%$ & $52.2 \%$ \\
Concern for quality, for things well done (GCI-5) & $3.4 \%$ & $95.7 \%$ \\
Ability to work under pressure (GCI-6) & $3.4 \%$ & $95.7 \%$ \\
Problem-solving (GCI-7) & $10.3 \%$ & $56.5 \%$ \\
Teamwork (GCI-9) & $20.7 \%$ & $65.2 \%$ \\
Motivation, enthusiasm, appetite for learning (GCI-10) & $24.1 \%$ & $87 \%$ \\
\hline
\end{tabular}

\section{Discussion}

Despite the data on experimental mortality, the assessment of the vocational maturity of the entire initial sample $(n=41)$ yielded an average rate of 13.3 and minimum scores of 9 points, considering that more than half of the sample $(66 \%)$ obtained a score between 11 and 15 . This places the group of participants at low-scoring levels and an average percentile in respect to vocational maturity, with the tools used for this research. These data allow us to confirm the first hypothesis, in which it was set out that participants (applicants for academic support) will have a low level of vocational maturity in line with other studies [26]. They requested to participate in training actions on the basis that participants 
lack training for the purpose of being autonomous in seeking and managing internships, along the same lines as other research [38]. They also declared that they were aware of the greater responsibility entailed by autonomy and the very demanding workload maintained over time [39]. Considering the generic competences related to their university degrees, which are reflected in the study guides or in the syllabus from entry to university, it is necessary to highlight that none of the participants consulted the study guides, and they were first seen during the tutoring carried out in the training program. With regard to these results, together with the results of the analysis of the information that students have of generic competences depending on the academic year, it is disturbing to note no statistical significance since similar results were obtained for third and fourth-year students, as for first-year ones (in previous surveys). This raises the issue of whether these same skills are being properly developed by teachers in their subjects, since today, university teaching should be guided to the acquisition of professional skills of a specific nature, besides those competences that are considered to be basic, generic, and transversal [40]. The teachers appear to accept training in generic competences, though their incorporation into teachers' daily activities and the academic curriculum are regarded with doubt [3,27]. On the other hand, it could also reflect indifference toward competences by students who consider their incorporation into the labor market as being a long way off, as well as uncertain [41].

As established above, tutoring has become a fundamental part of training, and it is key to individualized instruction and, at the same time, adapted to the educational needs of students with the intention of achieving high-quality communication between teachers and students [42]. It is also considered to be an essential factor to promote autonomous learning and the development of the whole person in an increasingly complex world [31]. Even though tutoring has always been carried out at the university, it is one of the main aspects that needs to be promoted to improve the quality of higher education [3].

The results of this study warn us of the lack of knowledge about the meaning of generic and transversal competences across all university degrees, as well as their limited development that entails a problem for the incorporation of internships at companies, and even, at a future workplace. Knowledge of these competences is a requirement raised and demanded by companies, and it has been detected as a particularly deficient aspect among the group of university graduates with disabilities in recent times [22]. Difficulties have been identified in the learning process [43], since skills related to communication, teamwork, and analysis have not been developed despite being referred to as essential and transversal skills in their professional futures by firms and organizations. There is some unanimity concerning the skills demanded by companies regardless of university studies, highlighting the abilities involved in teamwork, identification, and problem-solving, as well as creativity [44]. After considering the results of the knowledge of generic competences and transversal skills, and specifically, with regard to instrumental competences, which are the ones that were evaluated, as these competences are the first to be developed [45], interestingly, decision-making remains the competence that generates a greater lack of knowledge among participants after the implementation of the training program, despite putting these skills into practice in the choice of university studies. It may be influenced by the fact that on many occasions the "family council" has been one of the most compelling reasons behind their choice of one degree or another. According to [46], another possible explanation may be based on pre-university guidance, from which, in many of the sample cases, students have been advised with respect to the selection of university studies independently of their own abilities and motivations. It is precisely the volitional component that may be critical in promoting students' profound knowledge, not only of the contents of the degree but also of possible future professional development. It is therefore recommended that training in instrumental competences through tutoring needs to be continued, with the main aim of guiding and assisting students during the learning process [32]. Finally, we have been able to verify the increase in vocational maturity after the implementation of the training program in transversal skills. These include key behaviors, such as concern for quality, the ability to work under pressure, information management, and motivation [47]. These skills, equally important in academic and personal life, are also necessary for both access to internship and obtaining 
and maintaining a job since current selection processes focus not so much on experience or knowledge as on the interviewee's skills [21].

\section{Conclusions}

In light of the data obtained, and considering the above, it is first suggested that the continuation and improvement of the training action building partnership with the rest of the educational personnel should include transversal skills in the syllabuses in a coordinated way. Since the knowledge of the competences is the same in the third and fourth years, it makes us consider if we are training students on competences correctly in university classrooms. Secondly, it is important to further develop and strengthen the action plans in coordination with teachers to improve the quality of education $[3,48]$, as tutoring has become a fundamental part of training, and it is key to individualized instruction and, at the same time, adapted to the educational needs of students with the intention of achieving high-quality communication between teachers and students. Thirdly, it is necessary for the university to carry out programs that increase vocational maturity through training and guidance in general skills, as they are a requirement demanded by companies and improve access to internships and completion of studies. So, it is necessary to continue with pre-employment procedures, as they are effective in supporting students [49]. Fourthly, the role of disability support offices at universities, and their contribution to more inclusive higher education, needs to be highlighted. Finally, although this study provides relevant data on the situation of university students with disabilities, it has several limitations. First of all, the small size of the sample did not allow us to assess the degree of generality of reported experiences. The diversity of qualifications that students are undertaking would be illustrative of a particular trend, always analyzing the data with caution. It would be advisable not only to ensure a wider choice of students with disabilities at Rey Juan Carlos University and other institutions, but also to obtain data on students without disabilities, in the hope that these results could be compared. It would be also useful to assess a specific test of skills to provide greater consistency in subsequent research.

To conclude, we would like to point out the positive attitude and involvement of students while carrying out the assessment questionnaire on generic competences and the implementation of the training program, since the students realized for the first time that university studies come to an end and they have to face, independently, the search for and achievement and maintenance of employment. What is also remarkable was their positive attitude toward themselves, considering the training program by the Disability Support Office and Special Educational Needs at Rey Juan Carlos University, and the Disability Support Office itself as an essential service throughout their academic journey.

Author Contributions: Conceptualization, R.E.-C., R.M.-R., and C.J.; data curation, R.E.-C., formal analysis, R.E.-C., R.M.-R., and C.J.; methodology, R.E.-C., R.M.-R., and C.J.; visualization, R.E.-C., R.M.-R., and C.J.; writing-original draft, R.E.-C., R.M.-R., and C.J.; writing-review and editing, R.E.-C., R.M.-R., and C.J. All authors have read and agreed to the published version of the manuscript.

Funding: This research received no external funding.

Conflicts of Interest: The authors declare no conflict of interest.

\section{References}

1. Biggs, J. Calidad del Aprendizaje Universitario; Narcea: Madrid, Spain, 2005.

2. Huber, G.L. Aprendizaje activo y metodologías educativas. Rev. Educ. 2008, 59-84. Available online: http://www.educacionyfp.gob.es/revista-de-educacion/numeros-revista-educacion/ numeros-anteriores/2008/re2008/re2008-04.html (accessed on 2 November 2020).

3. Rodríguez-Izquierdo, R.M.-R. Modelo formativo en el Espacio Europeo de Educación Superior: Valoración de los estudiantes. Aula Abierta 2014, 42, 106-113. [CrossRef]

4. Rué, J. Enseñar en la Universidad; El Espacio Europeo de Educación Superior como Reto para la Educación Superior: Madrid, Spain, 2007. 
5. Buscà, F.; Cladellas, L.; Calvo, J.; Martín, M.; Padrós, M.; Capllonch, M. Evaluación formativa y participativa en docencia universitaria: Un estudio sobre los artículos publicados en revistas españolas entre 1999 y 2009. Aula Abierta 2011, 39, 137-148.

6. De Miguel, M. Metodología de Enseñanza y Aprendizaje para el Desarrollo de Competencias; Alianza Editorial: Madrid, Spain, 2006.

7. Korbel, D.M.; Jennifer, L.; Wenzel, C.M.; Anderson, B.G. Collaboration Strategies to Facilitate Successful Transition of Students with Disabilities in a Changing Higher Education Environment. In Disability and Campus Services: New Directions for Higher Education; Harbour, W.S., Madaus, J.W., Eds.; Wiley Online Library: Hoboken, NJ, USA, 2011; Volume 154, pp. 17-25. [CrossRef]

8. Morinña, A.; López-Gavira, R.; Morgado, B. How do Spanish disability support offices contribute to inclusive education in the university? Disabil. Soc. 2017, 32, 1608-1626. [CrossRef]

9. Peralta, A. Libro Blanco Sobre Universidad y Discapacidad, 1th ed.; Real Patronato sobre Discapacidad, con la Colaboración del Ministerio de Educación y Ciencia, la Fundación Vodafone, ANECA y el CERMI: Madrid, Spain, 2007.

10. Fundación Universia. Guía de Atención a la Discapacidad en la Universidad; Fundación Universia: Madrid, Spain, 2016.

11. INE-Instituto Nacional de Estadística. Informe el Empleo de las Personas con Discapacidad 2012; INE: Madrid, Spain, 2014.

12. Ministerio de Educación. Las Políticas sobre Discapacidad en el Sistema Universitario Español; Secretaría General Técnica, Subdirección General del Documentación y Publicaciones: Madrid, Spain, 2011.

13. Moswela, E.; Mukhopadhyay, S. Asking for too much? The voices of students with disabilities in Botswana. Disabil. Soc. 2011, 26, 307-319. [CrossRef]

14. Moriña, A. 'We aren't heroes, we're survivors': Higher education as an opportunity for students with disabilities to reinvent an identity. Furth. High Educ. 2017, 41, 215-226. [CrossRef]

15. CERMI. Un Plan de Empleo de las Personas con Discapacidad en el Siglo XXI; CERMI (Comité Español de Representantes de Personas con Discapacidad): Madrid, Spain, 2004; pp. 1-154.

16. CERMI. Guía para la Elaboración de un Plan de Atención al Alumnado con Discapacidad en la Universidad 2010; CERMI (Comité Español de Representantes de Personas con Discapacidad): Madrid, Spain, 2010; pp. 1-25.

17. Instituto Nacional de Estadística-INE. Encuesta de Integración Social y Salud 2012; INE: Madrid, Spain, 2014.

18. Scanlon, G.; Kamp, A.; Cochrane, A. Transition(s) to work: The experiences of people with disabilities in Ireland. Disabil. Soc. 2020, 35, 1556-1576. [CrossRef]

19. Espada-Chavarria, R. Madurez Vocacional en Estudiantes Universitarios con Discapacidad: Orientación y Formación en Competencias Transversales para la Mejora de la Empleabilidad y el Desarrollo Profesional. Ph.D. Thesis, University of Salamanca, Salamanca, Spain, 2016.

20. Espada-Chavarria, R.; González-Montesino, R. Desarrollo de Competencias Transversales para la Mejora de la Empleabilidad de Estudiantes Universitarios con Discapacidad; En La Universidad, motor de cambio para la inclusion; Vía Libre (ONCE): Madrid, Spain, 2018; pp. 399-407.

21. Capdevilla-Pagés, R. Los agentes de Intermediación. In Ponencia Presentada en las $3^{\circ}$ Jornadas sobre Empleo y Discapacidad. Acciones para un Empleo Cualificado; Universidad Carlos III: Getafe, Spain, 2009. Available online: http://hdl.handle.net/10016/11523 (accessed on 2 November 2020).

22. Cosculluela Martinez, C.; de Paz Cobo, S.; Rioboo Lestón, I. Mercado laboral, participación y diversidad social: Una aproximación multidisciplinar. In En Mujer y Trabajo I: Conciliación de la Vida Laboral; Ulzama Digital: Navarra, Spain, 2015; pp. 33-67.

23. Piggott, L.; Houghton, A.M. Disability and Transitions from Education to Work. Int. J. Lifelong Educ. 2007, 26, 573-587. [CrossRef]

24. Farley, R.; Bolton, B.; Little, N. Employability Assessment and Planning in Rehabilitation and Educational Settings. Vocat. Eval. Work Adjust. Bull. 1990, 23, 117-123.

25. Jenaro, C. Orientación Profesional en Personas con Discapacidad Desarrollo y Aplicación de Instrumentos de Evaluación e Intervención. Ph.D. Thesis, Universidad de Salamanca, Salamanca, Spain, 1997.

26. Rodríguez-Franco, P. Madurez Vocacional de Jóvenes Colombianos con Discapacidad: Evaluación en Intervención. Ph.D. Thesis, University of Salamanca, Salamanca, Spain, 2007. 
27. Corominas, E.; Tesouro, M.; Capell, D.; Teixidó, J.; Pèlach, J.; Cortada, R. Percepciones del profesorado ante la incorporación de las competencias genéricas en la formación universitaria. Rev. Educ. 2006, 341, 301-336. Available online: http://hdl.handle.net/10256/9861 (accessed on 2 November 2020). [CrossRef]

28. Carbonero, M. Aproximación Conceptual: Orientación Profesional y Asesoramiento. In Formación de Formadores: Estrategias de Orientación Laboral; Carbonero, M., Lucas-Mangas, S., Martín, L.J., Eds.; Junta de Castilla y León, Consejería de Industria, Comercio y Turismos: Valladolid, Spain, 2000; pp. 13-26.

29. Armengol, C.; Castro, D.; Jariot, M.; Massot, M.; Sala, J. El Practicum en el Espacio Europeo de Educación Superior (EEES): Mapa de competencias del profesional de la educación. Rev. Educ. 2011, 354, 71-98. Available online: http://hdl.handle.net/11162/80894 (accessed on 2 November 2020). [CrossRef]

30. Lapeña-Pérez, C.; Sauleda-Pares, N.; Martínez-Ruiz, A. Los programas institucionales de acción tutorial: Una experiencia desarrollada en la universidad de alicante. Rev. Investig. Educ. 2011, 29, 341-361.

31. González, J.; Wagenaar, R. Tuning Educational Structures in Europe; University of Deusto: Bilbao, Spain, 2003; pp. 1-338.

32. Lobato, C.; Guerra, N. Las Tutorías universitarias en el contexto europeo. Orient. Soc. 2014, 14, 1-22.

33. Madaus, J.W. The History of Disability Services in higher education. New Dir. High. Educ. 2011, 154, 5-15. [CrossRef]

34. Instituto Nacional de Estadística (INE). Anuario Estadístico de la Comunidad de Madrid. 1985-2018: Educación, Formación e Investigación; Instituto Nacional de Estadística: Madrid, Spain, 2018.

35. Diaz-Vega, M.; Moreno-Rodriguez, R.; Lopez-Bastias, J.L. Educational Inclusion through the Universal Design for Learning: Alternatives to Teacher Training. Educ. Sci. 2020, 10, 303. [CrossRef]

36. Roessler, R.; Bolton, B. Vocational Rehabilitation of Individuals with Employability Skill Deficits: Problems and Recommendations; Arkansas Rehabilitation Services: Fayetteville, AR, USA, 1984.

37. Morelock, K.; Roessler, R.; Bolton, B. The Employability Maturity Interview: Reliability and construct validity. Vocat. Eval. Work Adjust. Bull. 1987, 20, 53-59.

38. Broc-Cavero, M.A. Voluntad Para Estudiar, regulación del esfuerzo, gestión eficaz del Tiempo y rendimiento académico en alumnos Universitarios. Rev. Investig. Educ. 2011, 29, 171-185. Available online: https: //revistas.um.es/rie/article/view/110731 (accessed on 2 November 2020).

39. Ortiz, V.M.; Jenaro, C.; Meilán, J.G.; Zubiauz, B.; Mayor, M.A.; Arana, J.M. Carga de Trabajo en el EEES: La necesidad de coordinación docente entre asignaturas. In En actas de las IX Jornadas de Redes de Investigación en Docencia Universitaria; Universidad de Alicante: Alicante, Spain, 2011; pp. 1-15. Available online: https://www.researchgate.net/publication/267505972_Carga_de_Trabajo_en_el_EEES_La_necesidad_ de_coordinacion_docente_entre_asignaturas (accessed on 2 November 2020).

40. Semeijn, J.H.; Van der Velden, R.; Heijke, H.; Van der Vleuten, C.; Boshuizen, H.P.A. Competence indicators in academic education and early labour market success of graduates in health sciences. J. Educ. Work 2005, 19, 383-413. [CrossRef]

41. Moreno-Rodríguez, R. Conclusiones del Curso de Verano Discapacidad vs Empleo: Aspectos a Considerar para la Inclusión en el Empleo Ordinario; Servicio de Publicaciones de la Universidad Rey Juan Carlos: Madrid, Spain, 2013; pp. 1-204.

42. Egido Gálvez, I.; Cerrillo-Martin, R.; Durantes, A.C. La inclusión social y laboral de las personas con discapacidad intelectual mediante los programas de empleo con apoyo. Un reto para la Orientación. Rev. Española Orient. Psicoped. 2009, 20, 135-146. [CrossRef]

43. Oliveira, M.; Mazera, S.M.; Guillaumon, M.L.; Fernández, E. Análisis de la producción científica en Brasil sobre dificultades de aprendizaje: Una revisión bibliométrica. Aula Abierta 2014, 42, 31-38. [CrossRef]

44. Cárdenas-García, P.; Pulido-Fernández, J.; Carrillo-Hidalgo, I. Adquisición de competencias en el Grado de Turismo mediante el aprendizaje basado en estudios de caso. Aula Abierta 2016, 44, 15-22. [CrossRef]

45. Villa-Sánchez, A.; Poblete-Ruíz, M. Aprendizaje Basado en Competencias. Una Propuesta para la Evaluación de las Competencias Genéricas; Ediciones Mensajero, Universidad de Deusto: Bilbao, Spain, 2007; p. 336. Available online: http://biblio.upmx.mx/textos/14633.pdf (accessed on 2 November 2020).

46. López-Bastías, J.L.; Moreno-Rodriguez, R.; Espada-Chavarria, R.M.-R. El acceso a la universidad en estudiantes con discapacidad: La influencia de la orientación educativa en la elección de estudios de grado. Psychol. Soc. Educ. 2020, 12, 1-17. [CrossRef] 
47. Centro de Alto Rendimiento de Accenture (CAR) y Universia. Estudio “Las Competencias Profesionales en los Titulados. Contraste y Dialogo y Universidad y Empresa". 2007. Available online: https://ice.unizar. es/sites/ice.unizar.es/files/users/leteo/bibliografia/resumenejecutivoestudiocompetencias.pdf (accessed on 2 November 2020).

48. Martínez, M.; Viader, M.; Reflexiones sobre aprendizaje y docencia en el actual contexto universitario. La promoción de equipos docentes. Rev. Educ. 2008, 213-234. Available online: http://hdl.handle.net/11162/ 72290 (accessed on 2 November 2020).

49. Botham, K.A.; Nicholson, J. Supporting the transition of disabled students from university to practice placement. Disabil. Soc. 2014, 29, 460-476. [CrossRef]

Publisher's Note: MDPI stays neutral with regard to jurisdictional claims in published maps and institutional affiliations.

(C) 2020 by the authors. Licensee MDPI, Basel, Switzerland. This article is an open access article distributed under the terms and conditions of the Creative Commons Attribution (CC BY) license (http://creativecommons.org/licenses/by/4.0/). 